\title{
Panel Cointegration and Granger Causality Approach to Foreign Direct Investment and Economic Growth in Some Selected Emerging Economies
}

\author{
Aderemi Timothy Ayomitunde - Olayemi Henry Omotayo - \\ Adejumo Akintoye Victor - Yusuff Fatai Abolore*
}

\begin{abstract}
:
The aim of this study is to investigate the relationship between foreign direct investment and economic growth in seven emerging countries. Past empirical studies have failed to estimate the long run relationship between the variables in these countries, which has created a gap in the literature. Data was collected from the United Nations Conference on Trade and Development and World Bank Indicator from 1990 to 2017, and the Johansen Fisher Panel Cointegration and Pairwise Dumitrescu Hurlin Panel Causality Tests were utilised to address the objective of the study. Consequently, the empirical results show that FDI, GDP per capita, growth rate and economic growth have a long run equilibrium relationship. Also, there is an existence of one-way feedback which runs from FDI to economic growth. Based on these findings, this study recommends among others that the policy makers in the emerging countries should ensure the sustainability of the rate of economic growth and embark on more foreign investment-oriented policies that would catalyse further attraction of FDI inflows into their economies.
\end{abstract}

Key words; FDI; GDP; Growth Rate; Long Run Relationship and Emerging Countries

JEL Classification: F21, F23, F36, G24

\section{Introduction}

In the past few decades, European countries were the popular destination of FDI inflows. The estimated aggregate FDI inflows between 1970 and 2017 in this economic block occupied 38\% of global FDI inflows within those years which has

\footnotetext{
*Aderemi Timothy Ayomitunde; Olabisi Onabanjo University, Department of Economics, , Ago Iwoye, Nigeria, <Aderemi.timothy@gmail.com>.

Olayemi Henry Omotayo; Olabisi Onabanjo University, Department of Economics, Ago Iwoye, Nigeria,<Henri_ola1006@yahoo.com>.

Adejumo Akintoye Victor; Obafemi Awolowo University, Department of Economics, Ile-Ife, Nigeria. <adejumoakinvic@gmail.com>.

Yusuff Fatai Abolore; Obafemi Awolowo University, Department of Economics, Ile-Ife, Nigeria, <abdulffataiyusuff@gmail.com>.
} 
Aderemi et al: Panel Cointegration and Granger Causality Approach to Foreign Direct Investment and Economic Growth in Some Selected Emerging Economies.

positioned the region to be the highest recipient of global FDI inflows in the last 47 years (UNCTADstat, 2018). However, in the last decade, the attention of foreign investors has shifted towards newly emerging economies of the world, especially emerging economies in the South and East Asian sub regions (ADB, 2007). UNCTAD investment report shows that some emerging economies such as China, Hong Kong, Singapore, Brazil, India and Russia occupied the top ladder of FDI inflows recipients in 2016. As a matter of fact, China received the second highest global FDI inflows after the US in 2017. The exceptional performance of these countries regarding FDI inflows has created a global attention among the researchers and policy makers in the recent time. However, China, India, Brazil, Hong Kong, Singapore, Russia and South Africa have been selected for this study due to the similar macroeconomic indicators which these newly industrialised economies shared in the last decade. In the same vein, these economies have been identified with the incremental inflows of FDI on the annual basis which has made them to be a focal point of research. However, the focus of empirical studies of FDI inflows in these countries has recently orchestrated various arguments regarding the factors that derive the sporadic inflows of cross-border investment in these countries; see Aderemi et al. (2018), Bimal, (2017), Jadhav (2012) Vijayakumar et al. (2010), Janicki and Wunnava (2004) and Sahoo (2006). Whereas investment is one of the principal derivers of economic growth (Solow-Swan, 1956), it is worth of note that the traditional neoclassical models of growth which are a direct offshoot of the Harrod-Domar and Solow models emphasis the important role which investment plays in propelling the economic growth.

In the light of the above, liberalisation of a growing domestic economy cannot be undermined as it facilitates additional domestic and foreign investment which consequently increases the rate of capital accumulation. However, the seven emerging economies, namely China, India, Brazil, Hong Kong, Singapore, Russia and South Africa that are the focal point of this study have received a substantial amount of cross-border investment in the last decade. The answer to the question whether FDI inflows and economic growth have a long run relationship remains largely ambiguous for emerging economies; see Aderemi et al. (2019), Hudea and Stancu (2012), Acaravci and Ozturk (2012) Alfaro et al. (2004). Due to the inconclusive nature of literature regarding this subject matter it is pertinent to reexamine the long run relationship between cross-border investment and economic growth of some selected emerging countries in the recent time. Therefore, this study will move the frontiers of knowledge in this regards by examining the long run relationship between FDI inflows and economic growth in these countries. The uniqueness of this work also lies in examining the direction of causality between FDI inflows, growth rate and economic growth in these emerging economies, in which area the bulk of the past studies has recently failed. 


\section{Literature Review}

The theoretical foundation for explanation of FDI inflows is laid in the popular work of Heckscher-Ohlin neoclassical trade theory with the basic assumptions of perfectly competitive markets, constant returns to scale and zero transportation costs (Faeth, 2009). Consequently, different capital intensities facilitate FDI to flow among countries because countries with abundant capital move production to labour-abundant countries with higher returns to capital and lower returns to labour. It is worth of note that this process continues until returns to capital and labour are in equilibrium among countries. However, multinational companies are the major players in direct investment flows and the underlined factors that described these companies are economies of scale, specialisation via huge research and development expenditures and marketing. In order to build a model that would consider these specific features of multinational companies, John Dunning put forward a robust model which captures the firm-level and trade theory perspective in the Investment Development Path (IDP). In this model, five stages of development which could predict if a country would be a net inward or net outward investor were identified. Meanwhile, the strategic variables that determine the flow of FDI in this model are ownership specific (competitive), location-bound and internalisation advantages (Dunning and Narula, 1996). The model is popularly tagged OLI framework (Ownership-Location Internalisation) in the literature. Explicitly, the investing enterprise needs to possess an advantage in terms of technical knowledge, established brand through international marketing and advanced research and development centres over locally owned companies (Ownership). In the same vein, location specific advantages attract foreign multinationals to the host (Location). This could be qualities that are underlying and very difficult to influence like a large market size with huge demand or proximities of potential importing countries, economic and political environment and incentives that countries can affect over time. Finally, there should be a benefit of incorporating the new affiliate in the enterprise system rather than accessing markets through licensing (Internalization). Beneficial internalisation implies unique and productive corporate governance that for example lowers transaction costs and decreases imperfect information.

\subsection{Relationship between FDI Inflows and Economic Growth}

Yao and Wei (2007) analysed the role of FDI in promoting growth through production efficiency, technology and knowledge in some newly industrialised economies. The authors submitted that FDI is a principal stimulant that could catalyse the economic growth of newly industrialised economies to converge with the most developed economies of the world. 
Aderemi et al: Panel Cointegration and Granger Causality Approach to Foreign Direct Investment and Economic Growth in Some Selected Emerging Economies.

In another perspective, Chakraborty and Nunnenkamp (2008) investigated the impact of FDI on the sectoral growth of India. It was discovered that FDI inflows into service sector seem to have promotional effects on manufacturing industries via spill-overs of cross-sector leading to economic growth of the country.

Aderemi et al. (2019) adopted the Johansen Fisher Panel Cointegration and Pairwise Dumitrescu Hurlin Panel Causality Tests to investigate the relationship between foreign direct investment and economic growth in BRICS countries. The findings from the paper submitted that foreign direct investment, growth rate and economic growth have a long run equilibrium relationship with one another. One way feedback relationship also runs from FDI to economic growth in those countries.

Sauwaluck (2012) estimated the relationship between foreign direct investment and economic growth in South Korea from 1980 to 2009 with the application of multiple regression analysis. The results from the estimated model confirmed the existence of a direct and strong relationship between FDI and economic growth. However, domestic investment and economic growth have no significant positive relationship between each other in the country.

Alfaro et al. (2004) utilised data from OECD countries to evaluate the effect of FDI on economic growth. The authors found out, among other things, that the role of FDI alone in promoting economic growth is ambiguous in those countries. However, it was concluded from the study that the countries which possess well-developed financial markets benefited from FDI inflows significantly. Falki, (2009) utilised Ordinary Least Square to investigate the link between FDI and economic growth in Pakistan from 1980 to 2006. The author posited that an insignificant negative relationship existed between FDI and GDP in the country. Agrawal and Aamir (2011) employed OLS model to investigate the relationship between FDI and economic growth in China and India between 1993 and 2009. The estimated results of OLS showed that a unit increment in FDI led to $0.07 \%$ rise in GDP of China and $0.02 \%$ rise in GDP of India concurrently. It was also discovered from the study that more investors preferred to invest in China than India because the former has a larger market size than the latter and as a result of this, China's growth is more affected by FDI than India's growth.

However, Hoang et al. (2010) adopted a panel data analysis to assert that FDI had a strong and direct impact on economic growth of the country through the increment of capital stock. However, human capital and trade did not show connection to technological advancement and knowledge transfer as a channel through which the Vietnam's economic growth can be improved. Mallick and Moore (2008) pooled data from sixty developing economies between 1970 and 2003 with the application of the endogenous growth model. The study discovered the existence of a significant direct relationship between FDI inflows and economic growth in all 
income groups whereas in the lower income group countries FDI has an indirect effect on economic growth via its weaker contribution to investment in those countries. Hudea and Stancu (2012) applied a panel data to analyse the nexus between foreign direct investments, technology transfer and economic growth of East European nations during the period of 1993 -2009. The researchers submitted that there was an existence of a direct relationship between FDI and economic growth in the seven countries under investigation in the both short run and long run.

Acaravci and Ozturk (2012) employed ARDL and bounds testing approach to analyse the nexus between FDI, export and economic growth in the new European Union countries. The study discovered a long-run relationship among the variables of interest. Similarly, there was an existence of causal relationship between export, FDI and economic growth in four countries while reverse was the case of the other six countries in the study.

\subsection{Determinants of FDI inflows in host economies}

Vijayakumar et al. (2010) critically examined what derives FDI inflows in BRICS countries with the aid of a panel data analysis. The authors identified market size, labour cost, infrastructure and gross capital formation as the major factors that derive FDI inflows in the countries. But trade openness and inflation are posited to be insignificant variables that derive FDI inflows in those economies. Aderemi et al. (2018) analysed the performance of FDI inflows in seven newly industrialised nations on a comparative basis between 1990 and 2017. It was discovered from the study that the prominent drivers of FDI inflows in Chinese economy are the large market size, growth rate and GDP per capita growth. However, in Brazilian, Indian, South African, Singaporean and Hong Kong economies, it was only the market size that propelled FDI inflows. Also, in Russia and South Africa, GDP per capita growth was recognised as an insignificant variable that derived FDI inflows in those two countries.

Similarly, Mottaleb and Kalirajan (2010) conducted a comparative analysis of the factors that determine foreign direct investment in 68 developing economies. It was discovered from the study that some economies are doing very well in attracting FDI and some are not. Also, following the estimation of a panel data analysis of 68 low income countries, the authors submitted that countries with higher level of GDP or GDP growth rate have upper hands to attract more FDI.

Consequently, Alalaya (2010) estimated Auto Regressive Distribution Lag (ARDL) model to capture FDI and growth rate of Jordan over the period of 1990 to 2008. The researcher discovered a significant high speed of adjustment along with a unidirectional feedback effect which runs from FDI to growth rate of the economy. 
Aderemi et al: Panel Cointegration and Granger Causality Approach to Foreign Direct Investment and Economic Growth in Some Selected Emerging Economies.

Consequently, the above reviewed literature indicates that studies are ongoing about the relationship between FDI inflows and important macro-economic variables such as GDP and growth rate in the host economies, especially developing countries. However, the literature has not yet reached a consensus about this relationship and thus the relevancy of this work.

\subsection{Role of FDI in host countries}

The role of FDI inflows in the host economies could be viewed from two perspectives, namely static role and dynamic role. Static effect is a short run phenomenon which has to do with a direct impact of FDI inflow on capital accumulation. This consequently raises the potential production level (Alquacil et al., 2008). However, in spite of the fact that FDI causes the creation of new facilities, it has been argued that this cross-border investment tends to crowd in domestic investment in the developing economies (Razin et al. 1999). Meanwhile, it is instructive to stress that the dynamic effects of FDI inflows are more important in the host countries because they result in economic growth over a longer period of time. Larger bulk of FDI flows from multinational enterprises which possess high research and development expenditures, advanced technology and process machinery, established marketing system and unique management which invariably spread to the newly established affiliates in the host countries. In addition, other spill-over effects of these multinationals on domestic enterprises could be identified through the process of learning-by-doing, such as a situation whereby the employees copy and learn a new technique of production and management. For example, there could be a positive spill-over effect in horizontal level when local companies in the same or similar production domain with multinationals hire experts or professionals from MNCs or interact with them in some platforms. In another scenario, positive externality could emanate when workers leave the multinational enterprises to set up their own companies with a view to use the professional experience acquired over time from the multinationals (Alfaro and Rodriguez-Clare, 2004).

Consequently, the spill-over theory is universally accepted in all the countries, however, certain variables orchestrate the positive externalities of FDI in the host countries. In one hand, it has been argued that new technologies introduced by FDI into the domestic economies should be complemented by old (domestic) technologies in order to ensure dynamic effects. On the other hand, spill-over effects are higher in economies that have lower technology gap between the investor and the host economies. This implies that less technological oriented economies are linked with difficulties in absorbing advanced techniques and experience and hence a decrease in productivity (Demekas et al. 2005). 


\subsection{Overview of some selected economic indicators in the countries under study}

Figure1 shows the GDP per capita growth which measures the standard of living in an economy. It could be pinpointed from the figure above that in the last decade (2007-2017), the average GDP per capita growth is the best in China, followed by India and Singapore, Russia and Brazil, respectively. On the other hand, South Africa`s average performance indictor is the least among these emerging countries. It should be noted that from 2014 to 2016, Brazil and Russia registered negative GDP per capita growth. Meanwhile, South Africa recorded negative GDP per capita growth in 2015 and 2016 as well. This set back in Brazil and South Africa might be linked to corruption and political upheavals in those countries within the periods in question. It is worth to stress that in the last decade, it is only China and India that have been very consistent in growing their GDP per capita with little marginal fluctuations.

Tab. 1 GDP/CA Growth in the Selected Countries (Annual \%)

\begin{tabular}{lrrrrrrr}
\hline Year/Country & China & Brazil & India & South Africa & Russia & Hong Kong & Singapore \\
\hline 2007 & 13.60 & 4.90 & 8.20 & 4.3 & 8.7 & 5.6 & 4.7 \\
2008 & 9.10 & 4.00 & 2.4 & 2.1 & 5.3 & 1.5 & -3.5 \\
2009 & 8.90 & -1.10 & 7.00 & -2.6 & -7.8 & -2.7 & -3.6 \\
2010 & 10.60 & 6.50 & 8.80 & 1.8 & 4.5 & 6.0 & 13.2 \\
2011 & 9.00 & 3.00 & 5.20 & 1.9 & 5.2 & 4.1 & 4.2 \\
2012 & 7.30 & 1.00 & 4.10 & 0.8 & 3.5 & 0.6 & 1.6 \\
2013 & 7.20 & 2.10 & 5.10 & 1.0 & 1.6 & 2.7 & 3.4 \\
2014 & 6.80 & -0.40 & 6.10 & 0.4 & -1 & 2.0 & 2.5 \\
2015 & 6.40 & -4.40 & 6.90 & -0.1 & -3 & 1.5 & 1.0 \\
2016 & 6.10 & -4.30 & 5.90 & -0.7 & -0.4 & 1.5 & 1.1 \\
2017 & 6.30 & 0.20 & 5.40 & 0.1 & 1.4 & 3.0 & 3.5 \\
Average & 8.30 & 1.00 & 6.00 & 0.8 & 2.8 & 2.3 & 2.8 \\
\hline
\end{tabular}

Source: authors' computation (2019) from WDI, 2018.

Table 2 shows an overview of economy performance in term of growth rate of these selected countries. It could be deduced that over the last decade (2007-2017), the average growth rate in China is the fastest. In the same vein, India and Singapore are the second and third fastest growing economies among the studied economies. It is worth of note that Brazil, South Africa and Russia Federation reported a noticeable growth rate in 2007, 2008, 2010 and 2011, whereas Hong Kong 
Aderemi et al: Panel Cointegration and Granger Causality Approach to Foreign Direct Investment and Economic Growth in Some Selected Emerging Economies.

registered an impressive growth rate in 2007, 2010 and 2011. The Russian economy is the least growing economy among these seven countries considered for analysis. However, Brazil and Russia recorded negative growth in 2015 and 2016, respectively. Chinese and Indiana economies are the fastest growing economies with the huge market size orchestrated by their teeming populations.

\section{Tab. 2 Economic Growth Rate in the Selected Countries (Annual \%)}

\begin{tabular}{lrrrrrrr}
\hline Year/Country & China & India & Brazil & South Africa & Russia & Hong Kong & Singapore \\
\hline 2007 & 14.2 & 9.8 & 6.1 & 5.4 & 8.2 & 9.1 & 6.5 \\
2008 & 9.7 & 3.7 & 5.1 & 3.2 & 5.2 & 1.8 & 2.1 \\
2009 & 9.4 & 8.5 & -0.1 & -1.5 & -7.8 & -0.6 & -2.5 \\
2010 & 10.6 & 10.3 & 7.5 & 3.0 & 4.5 & 15.2 & 6.8 \\
2011 & 9.5 & 6.6 & 4.0 & 3.3 & 5.3 & 6.4 & 4.8 \\
2012 & 7.9 & 5.5 & 1.9 & 2.2 & 3.7 & 4.1 & 1.7 \\
2013 & 7.8 & 6.4 & 3.0 & 2.5 & 1.8 & 5.1 & 3.1 \\
2014 & 7.3 & 7.4 & 0.5 & 1.8 & 0.7 & 3.9 & 2.8 \\
2015 & 6.9 & 8.2 & -3.5 & 1.3 & -2.8 & 2.2 & 2.4 \\
2016 & 6.7 & 7.1 & -3.5 & 0.6 & -0.2 & 2.4 & 2.2 \\
2017 & 6.3 & 6.6 & 1.0 & 1.3 & 1.5 & 3.6 & 3.8 \\
Average & 8.8 & 7.3 & 2.0 & 2.1 & 1.8 & 4.8 & 3.1 \\
\hline
\end{tabular}

Source: authors' computation (2019) from WDI, 2018.

\section{Data and Methodology}

This study extracted secondary data of seven emerging countries from 1990 to 2017. The counties are as follows: China, India, Brazil, Russian Federation, Singapore, Hong Kong and South Africa. Data on FDI, GDP and growth rate were sourced from UNCTAD database published by World Bank and World Development Indicator simultaneously. The analysis of the data was carried out with the aid of Eviews software.

In estimating panel cointegration for this study, the pioneering work of Johansen and Juselius (1990) was adopted. The Trace statistics and Maximum eigenvalue statistics of this model can be calculated from the eigenvalues of the coefficient matrix. It is important to indicate that the null hypothesis of the Trace statistics is that there are at most $\boldsymbol{r}$ cointegrations among the variables. Meanwhile, the alternative hypothesis is stated that there are more than $\boldsymbol{r}$ cointegrations among the variables ditto for and the maximum eigenvalue statistics test. Moreover, the causal 
relationship between the variables can be estimated using the recently-developed panel causality test, Dumitrescu and Hurlin (DH) causality test. This test was put forward by Dumitrescu and Hurlin (2012), and the model can be modified as follows:

$$
\begin{aligned}
& G D P_{i t}=\alpha_{1 i 0}+\sum_{x=1}^{p 1} \alpha_{i 1}^{(x)} G D P_{i t-x}+\sum_{x=1}^{p 2} \alpha_{i 2}^{(x)} G R T_{i t-x}+\sum_{x=1}^{p 3} \alpha_{i 3}^{(x)} F D I_{i t-x}+\varepsilon_{1 i t} \\
& G R T_{i t}=\alpha_{2 i 0}+\sum_{x=1}^{p 1} \alpha_{i 1}^{(x)} G R T_{i t-x}+\sum_{x=1}^{p 2} \alpha_{i 2}^{(x)} G D P_{i t-x}+\sum_{x=1}^{p 3} \alpha_{i 3}^{(x)} F D I_{i t-x}+\varepsilon_{2 i t} \\
& F D I_{i t}=\alpha_{3 i 0}+\sum_{x=1}^{p 1} \alpha_{i 1}^{(x)} F D I_{i t-x}+\sum_{x=1}^{p 2} \alpha_{i 2}^{(x)} G R T_{i t-x}+\sum_{x=1}^{p 3} \alpha_{i 3}^{(x)} G D P_{i t-x}+\varepsilon_{3 i t} \\
& G D P / C A_{i t}=\alpha_{4 i 0}+\sum_{x=1}^{p 1} \alpha_{i 1}^{(x)} G D P / C A_{i t-x}+\sum_{x=1}^{p 2} \alpha_{i 2}^{(x)} G R T_{i t-x}+\sum_{x=1}^{p 3} \alpha_{i 3}^{(x)} F D I_{i t-x}+
\end{aligned}
$$

$\varepsilon_{4 i t}$

Where: GDP is real gross domestic product which is used to proxy economic growth and is measured in US dollars. In the same vein, FDI means foreign direct investment inflows, measured in millions US dollars in constant prices. GDP/CA is used to denote gross domestic product per capita, measured as a percentage. GRT is used to proxy the growth rate of the economy and it is measured as a percentage. $\varepsilon_{1 t}, \varepsilon_{2 t}, \varepsilon_{3 t}$ and $\varepsilon_{4 t}$ represent stochastic error terms, $\boldsymbol{x}$ is the lag length, while $\boldsymbol{i}=1 \ldots .7$ and $\mathrm{t}=1990-2017$.

\section{Results and Discussion}

Table 3 estimates a panel unit root to verify the stationarity of the data employed for the study. As shown in the table, the results from the estimated Panel ADF Test and Panel PP Test of variables growth rate and GDP per capita are I (0) variables; meaning the variables are stationary at level. However, Panel PP Test and Panel ADF Test confirmed that FDI and real GDP possessed unit roots. The variables are

\begin{tabular}{|c|c|c|c|c|c|c|c|}
\hline \multicolumn{6}{|c|}{ Panel ADF Test } & \multicolumn{2}{|c|}{ Panel PP Test } \\
\hline Variables & Level & $1^{\text {st }}$ Diff & $\begin{array}{l}2^{\text {nd }} \\
\text { Diff. }\end{array}$ & Remarks & Level & $1^{\text {st }}$ Diff. & Remarks \\
\hline RGDP & $3.3 \mathrm{E}-11$ & 1.12939 & 96.1754 & $\mathrm{I}(2)$ & $6.9 \mathrm{E}-06$ & 44.0631 & $\mathrm{I}(1)$ \\
\hline GRT Rate & 37.5324 & ----- & ----- & $\mathrm{I}(0)$ & 46.1163 & --- & $\mathrm{I}(0)$ \\
\hline FDI & 2.42578 & 88.5577 & ----- & $\mathrm{I}(1)$ & 1.88436 & 158.935 & $\mathrm{I}(1)$ \\
\hline GDP/CA & 41.4964 & ------ & ----- & $\mathrm{I}(0)$ & 53.7861 & ------ & $\mathrm{I}(0)$ \\
\hline
\end{tabular}
indicated to be I (1) variables, but became stationary after first differencing, apart from the result from Panel ADF Test which confirmed RGDP to be I (2).

\section{Tab. 3 Panel Unit Root Test}

Source: authors' computation. 
Aderemi et al: Panel Cointegration and Granger Causality Approach to Foreign Direct Investment and Economic Growth in Some Selected Emerging Economies.

\section{Tab. 4 Johansen Fisher Panel Cointegration Test}

1) Unrestricted Cointegration Rank Test (Trace and Maximum Eigenvalue)

\begin{tabular}{|c|c|c|c|c|}
\hline Hyp. No. of CE(s) & Fisher Stat. $^{1}$ (trace test) & Prob. & Fisher Stat. ${ }^{1}$ (max-eigen test) & Prob. \\
\hline None & 339.0 & 0.0000 & 250.9 & 0.0000 \\
\hline At most 1 & 51.28 & 0.0000 & 45.38 & 0.0000 \\
\hline At most 2 & 19.16 & 0.1590 & 23.25 & 0.0563 \\
\hline At most 3 & 0.723 & 1.0000 & 0.723 & 1.0000 \\
\hline \multicolumn{5}{|c|}{ 2) Individual cross section results } \\
\hline Cross Section & Trace Test Statistics & Prob. $^{2}$ & Max-Eigen Test Statistics & Prob. $^{2}$ \\
\hline \multicolumn{5}{|c|}{ Hypothesis of no cointegration } \\
\hline 1 & 154.5418 & 0.0000 & 122.3020 & 0.0000 \\
\hline 2 & 154.5418 & 0.0000 & 122.3020 & 0.0000 \\
\hline 3 & 154.5418 & 0.0000 & 122.3020 & 0.0000 \\
\hline 4 & 154.5418 & 0.0000 & 122.3020 & 0.0000 \\
\hline 5 & 154.5418 & 0.0000 & 122.3020 & 0.0000 \\
\hline 6 & 154.5418 & 0.0000 & 122.3020 & 0.0000 \\
\hline 7 & 154.5418 & 0.0000 & 122.3020 & 0.0000 \\
\hline \multicolumn{5}{|c|}{ Hypothesis of at most 1 cointegration relationship } \\
\hline 1 & 32.2399 & 0.0257 & 21.8861 & 0.0391 \\
\hline 2 & 32.2399 & 0.0257 & 21.8861 & 0.0391 \\
\hline 3 & 32.2399 & 0.0257 & 21.8861 & 0.0391 \\
\hline 4 & 32.2399 & 0.0257 & 21.8861 & 0.0391 \\
\hline 5 & 32.2399 & 0.0257 & 21.8861 & 0.0391 \\
\hline 6 & 32.2399 & 0.0257 & 21.8861 & 0.0391 \\
\hline 7 & 32.2399 & 0.0257 & 21.8861 & 0.0391 \\
\hline \multicolumn{5}{|c|}{ Hypothesis of at most 2 cointegration relationship } \\
\hline 1 & 10.3537 & 0.2545 & 10.3499 & 0.1900 \\
\hline 2 & 10.3537 & 0.2545 & 10.3499 & 0.1900 \\
\hline 3 & 10.3537 & 0.2545 & 10.3499 & 0.1900 \\
\hline 4 & 10.3537 & 0.2545 & 10.3499 & 0.1900 \\
\hline 5 & 10.3537 & 0.2545 & 10.3499 & 0.1900 \\
\hline 6 & 10.3537 & 0.2545 & 10.3499 & 0.1900 \\
\hline 7 & 10.3537 & 0.2545 & 10.3499 & 0.1900 \\
\hline \multicolumn{5}{|c|}{ Hypothesis of at most 3 cointegration relationship } \\
\hline 1 & 0.0038 & 0.9497 & 0.0038 & 0.9497 \\
\hline 2 & 0.0038 & 0.9497 & 0.0038 & 0.9497 \\
\hline 3 & 0.0038 & 0.9497 & 0.0038 & 0.9497 \\
\hline 4 & 0.0038 & 0.9497 & 0.0038 & 0.9497 \\
\hline 5 & 0.0038 & 0.9497 & 0.0038 & 0.9497 \\
\hline 6 & 0.0038 & 0.9497 & 0.0038 & 0.9497 \\
\hline 7 & 0.0038 & 0.9497 & 0.0038 & 0.9497 \\
\hline
\end{tabular}

Source: authors' computation.

${ }^{1}$ Probabilities are computed using asymptotic Chi-square distribution.

2 MacKinnon-Haug-Michelis (1999) p-values. 
Since the variables utilised for this study are mixture of $\mathrm{I}(0), \mathrm{I}(1)$ and $\mathrm{I}(2)$ it is expedient to examine their long run equilibrium, though they might show deviation in the short run. In order to capture this, a panel multivariate cointegration test was examined in the table above. Therefore, the estimated Johansen Fisher Panel Cointegration Test shows the presence of three cointegrating vectors in the systems. From the trace statistics and the maximal eigenvalue statistics it could be pinpointed that three cointegrating vectors exist in the model (at a lag interval of 1 to 1 ). From the above, it could be concluded that the variables FDI, growth rate, GDP per capita and economic growth in the system have a long run equilibrium relationship with one another. This implies that all the variables of interest in this study have a long run relationship. The economic implication of this finding is as follows: FDI inflows has been a driving force behind the consistent rise in the growth rate and GDP per capita which has eventually metamorphosed into economic growth in these countries in the long run. This submission is validated by the propositions of HarrodDomar and Solow growth models which emphasised investment as the principal factor that derives growth in an economy. In the case of these selected emerging economies, foreign investment inflows have been a strategic factor responsible for their economic growth. The finding in this study is in line with the conclusions of Hasibul and John (2017), Acaravci and Ozturk (2012) who carried out similar studies in SAARC countries and the new European Union countries, respectively. However, this finding contradicts the view of Bashir and Shakir (2012) in a related study focusing on the developing economies of Bangladesh and Maldives.

In order to determine the direction of causality between FDI, real GDP, GDP/CA and growth rate in the seven emerging countries selected for this work, a panel Granger causality test was estimated (see above).

\section{Tab. 5 Dynamic Test}

\begin{tabular}{lccc}
\hline Null Hypothesis: & W-Stat. & Zbar-Stat. & Prob. \\
\hline GRT_RATE does not homogeneously cause FDI & 36.4965 & 36.9220 & 0.0000 \\
FDI does not homogeneously cause GRT_RATE & 2.87940 & 0.72030 & 0.4713 \\
RGDP does not homogeneously cause FDI & 1.88679 & -0.34863 & 0.7274 \\
FDI does not homogeneously cause RGDP & 5.42077 & 3.45706 & 0.0005 \\
RGDP does not homogeneously cause GRT_RATE & 7.11276 & 5.27913 & $1 . E-07$ \\
GRT_RATE does not homogeneously cause RGDP & 8.57347 & 6.85214 & $7 . E-12$ \\
GDP_CA does not homogeneously cause FDI & 45.5278 & 46.6475 & 0.0000 \\
FDI does not homogeneously cause GDP_CA & 2.16202 & -0.05224 & 0.9583 \\
& & & \\
\hline
\end{tabular}


Aderemi et al: Panel Cointegration and Granger Causality Approach to Foreign Direct Investment and Economic Growth in Some Selected Emerging Economies.

The results from Table 5 can be put forward as follows: there is a unidirectional feedback effect which runs from growth rate to FDI inflows in the emerging countries. This implies that the growth rate of these countries is a propelling variable for the inflow of this cross-border investment in those economies. Similarly, the estimated result shows that there is a unidirectional causality which runs from FDI to economic growth in these emerging economies. It is worth of note that this finding corroborates the assertion of Harrod-Domar and Solow growth models, which both concluded that the necessary condition for economic growth is investment. Whereas, this this results contradicts the finding of Chakraborty and Basu (2002) who opined that there is a one way casual effect which runs from GDP to FDI inflows in India. In the same vein, there is a unidirectional causality which runs from GDP/Ca to FDI

\section{Conclusion}

In this work, an attempt has been made to carry out empirical study about the long run equilibrium relationship between FDI, GDP per capita, growth rate and economic growth in seven newly emerging economies within the period of 1990 to 2017. The methodology utilised for this study is Johansen Fisher Panel Cointegration and Pairwise Dumitrescu Hurlin Panel Causality Tests. Consequently, the finding from this empirical work establishes that long run equilibrium relationship exists among FDI, GDP per capita, growth rate of economy and economic growth in emerging countries under the period of analysis. The implication of this result is that the aforementioned economic variables have the high tendency to converge in the nearest future. In the same vein, inflows of FDI in these countries have the capacity to expand the quantum of goods and services in those countries thereby leading to economic growth in the long run. Also, the growth rate in these countries is the prominent variable propelling FDI inflows sporadically in the decades past. As a result of the findings that originated from this work, it is important to state that the policy makers in these emerging countries can manipulate the growth rate of their economies with a view of inducing the sporadic inflows of FDI which would later lead to economic growth of the countries in the long run.

Similarly, from the findings that originated from this empirical work there could be drawn vital policy recommendations for policy makers, investors, financial institutions regulators and future researchers. The policy makers from the selected countries analysed in this paper should come up with a sufficient strategic policy that would sustain the rate of economic growth in the countries. A conductive business climate that would facilitate further attraction of FDI inflows into all sectors of the economies should be embarked upon as well. 


\section{References}

Acaravci, A, Ozturk, I., 2012. Foreign Direct Investment, Export and Economic Growth: Empirical Evidence from New EU Countries. Romanian Journal of Economic Forecasting 15, 52-67. Available from: <ideas.repec.org/a/rjr/romjef/vy 2012i2p52-67.html>. [30 July 2019].

Aderemi, T. A., Adebayo, A. B., Jolayemi, L. B., Kalejaiye, G. T., 2019. Panel Cointegration and Granger Causality Approach to Foreign Direct Investment and Economic Growth in BRICS Countries. Acta Universitatis Danubius, Economica 15, 236-248.

Aderemi, T. A., Abalaba, B. P., Ebere C. E., Ojelade, L. O., 2018. Comparative Analysis Approach to Foreign Direct Investment and Economic Growth in Emerging Economies (1990-2017). Saudi Journal of Economics and Finance 2, 263-269.

Agrawal G., Khan, M. A., 2011. Impact of FDI on GDP: A Comparative Study of China and India. International Journal of Business and Management 6, 71-79. DOI: 10.5539/ijbm.v6n10p71.

Alalaya, M. M., 2010. ARDL models applied for Jordan trade, FDI and GDP series. European Journal of Social Sciences 13, 605-616.

Alfaro, L., Rodriguez-Clare, A., 2004. Multinationals and Linkages: An Empirical Investigation, Economia 4, 113-169. DOI: 10.1353/eco.2004.0012.

Alquacil, M., Cuadros, A., Orts, V., 2008. EU Enlargement and inward FDI, Rewiew of Development Economics 12, 594-604. DOI: 10.1111/j.14679361.2008.00474.x.

Bashir, R., Shakir, R., 2012. FDI and Economic Growth in SAARC: An Empirical Analysis. GMJACS 2, 65-75.

Bimal, S., 2017. Determinants of foreign direct investment in South Asia: Analysis of economic, institutional and political factors. Journal of South Asian Studies, 5(1), $1-11$.

Chakraborty, C., Basu, P., 2002. Foreign Direct Investment and Growth in India: A Cointegration Approach. Applied economics 34:9, 1061-1073. DOI: 10.1080/00036840110074079.

Chakraborty, C., Nunnenkamp, P., 2008. Economic Reforms, FDI, and Economic Growth in India: A Sector Level Analysis. World Development 36, 1192-1212. DOI: 10.1016/j.worlddev.2007.06.014.

Demekas, D. G., Horváth, B., Ribakova, E., Wu, Y., 2007. Foreign direct investment in European transition economies - the role of policies. Journal of Comparative Economics 35, 369-386. DOI: 10.1016/j.jce.2007.03.005. 
Aderemi et al: Panel Cointegration and Granger Causality Approach to Foreign Direct Investment and Economic Growth in Some Selected Emerging Economies.

Dumitrescu, E. I., Hurlin, C., 2012. Testing for Granger Non-causality in Heterogeneous Panels. Economic Modelling, 29, 1450-1460. DOI: 10.1016/j. econmod.2012.02.014.

Dunning, J. H., Narula, R., 1996. The investment development path revisited, in Foreign Direct Investment and Governments: catalysts for economic restructuring, Routledge, London.

Faeth, I., 2009. Determinants of Foreign Direct Investment- a Tale of Nine Theoretical Models, Journal of Economic Surveys 23, 165-196. DOI: 10.1111/j.1467-6419.2008.00560.x.

Falki, N. 2009. Impact of Foreign Direct Investment on Economic Growth in Pakistan. International Review of Business Research Papers 5, 110-120. Available from: <pdfs.semanticscholar.org/c4d7/c8aacaa5f856d5407461390620b282315beb .pdf.>. [30 July 2019].

Hasibul, I. R., John, K., 2017. Impact of Foreign Direct Investment on Economic Growth of the SAARC Countries. Journal of Economics and Sustainable Development 8, 58-66. Available from: <pdfs.semanticscholar.org/ae48/9ceab61 c0959a57da1bf65c90fddb5b2fbf6.pdf.>. [30 July 2019].

Hoang, T. T., Wiboonchutikula, P., Tubtimtong, B., 2010. Does Foreign Direct Investment Promote Economic Growth in Vietnam? Asean Economic Bulletin 2, 295-311. DOI: 10.1355/ae27-3d.

Jadhav, P., 2012. Determinants of Foreign Direct Investments in BRICS Economies: Analysis of Economic, Institutional and Political Factors. ProcediaSocial and Behavioral Sciences 37, 5-14. DOI: 10.1016/j.sbspro.2012.03.270.

Janiciki, P. H., Wunnava, P. V., 2004. Determinants of FDI investment empirical evidence from EU accession candidates. Journal of Applied Economics 36, 505509. DOI: $10.1080 / 00036840410001682214$.

Johansen, S., Juselius, K., 1990. Maximum Likelihood Estimation and Inference on Cointegration with Applications to Demand for Money. Oxford Bulletin of Economics and Statistics 52, 169-210. DOI: 10.1111/j.1468-0084.1990.mp5200 2003.x.

Hudea, O. S., Stancu, S., 2012. Foreign Direct Investments, Technology Transfer and Economic Growth: A Panel Approach. Romanian Journal of Economic Forecasting 15, 85-10.

Mallick, S., Moore, T., 2008. Foreign Capital in a Growth Model. Review of Development Economics 12, 143-159. DOI: 10.1111/j.1467-9361.2008.00437.x.

Motalleb, K. A., Kalirajan, K., 2010. Determinants of Foreign Direct Investment in Developing countries: A Comparative analysis. ASARC working paper 
2010/13. Available from: <asiaandthepacificpolicystudies.crawford.anu.edu.au/acd e/asarc/pdf/papers/2010/WP2010_13.pdf.>. [30 July 2019].

Razin, A., Sadka, E., Yuen, C., 1999. An Information-Based Model of Foreign Direct Investment: The Gains from Trade Revisited, International Tax and Public Finance 6, 579-596. DOI: 10.1023/a:1008709617617.

Rodriguez-Clare, A., 1996. Multinationals, linkages, and economic development the American Economic Review 86, 852-874. Available from: <econpapers.repec.org/article/aeaaecrev/v_3a86_3ay_3a1996_3ai_3a4_3ap_3a852 -73.htm>. [30 July 2019].

Sauwaluck K., 2012. International Journal of Business and Social Science 3, 8-18.

Sahoo, P., 2006. Foreign Direct Investment in South Asia: Policy, Trends, Impact and Determinants. ADB Institute Discussion paper No. 56.

Solow, R. M., 1956. A Contribution to the Theory of Economic Growth. The Quarterly Journal of Economics, 65-94. DOI: 10.2307/1884513.

Swan, T. W., 1956. Economic Growth and Capital Accumulation. Economic Record 32, 334-361. DOI: 10.1111/j.1475-4932.1956.tb00434.x.

United Nations Conference on Trade and Development (UNCTAD), 2018. World investment Report 2018. Available from: <unctad.org/en/PublicationsLibrary/wir 2018_en.pdf>. [11 August 2019].

Vijayakumar, N., Sridharan, P., Rao, K. C., 2010. Determinants of FDI in BRICS Countries: A Panel Analysis. International Journal of Business Science and Applied Management 5, 1-13. Available from: <business-andmanagement.org/library/2010/5_3--1--13-Vijayakumar,Sridharan,Rao.pdf.>. [30 July 2019].

World Bank, 2018. World Development Indicators. Washington D.C.

Yao, S. Wei, K., 2007. Economic growth in the presence of FDI: The perspective of newly industrializing economies. Journal of Comparative Economics 35, 211 234. DOI: 10.1016/j.jce.2006.10.007. 
